\title{
ДЕЯКІ ОСОБЛИВОСТІ УПРАВЛІННЯ ТА ДЕРЖАВНОГО РЕГУЛЮВАННЯ СИСТЕМИ ВИЩОЇ ОСВІТИ УКРАЇНИ В УМОВАХ ЄВРОПЕЙСЬКОЇ КОНВЕРГЕНЦІЇ ПРОСТОРОВО-ЕКОНОМІЧНИХ СИСТЕМ
}

Масляк Т. Р.

\section{ВСТУП}

Україна володіє потужним освітнім потенціалом та можливістю виходу вітчизняної освіти на світові ринки освітніх послуг. В умовах радикальних соціально-економічних перетворень відбулися зміни, які зумовили становлення та розвиток ринку освітніх послуг у країні. Внаслідок процесів глобалізації, європейської інтеграції та інформаційної революції відбуваються трансформаційні зрушення в національній системі освіти, наближення до принципів Болонського процесу. У контексті розвитку освітніх послуг в Україні інтеграційні фактори характеризують тенденцію, завдяки якій національні провайдери освіти на ринку освітніх послуг, що були обмежені у наданні своїх послуг державними кордонами, отримали можливість експортувати освітні послуги в країни Європейського Союзу, і навпаки. Євроінтеграційні процеси, будучи суттєвим викликом для вітчизняної системи освіти, одночасно дають значні можливості для розвитку ринків освітніх послуг у регіонах України ${ }^{1}$.

В умовах ринкових перетворень Україна опинилася перед необхідністю створення ефективного і дієвого ринку освітніх послуг та реалізації потенціалу висококваліфікованих фахівців. Розвиток ринку освітніх послуг - необхідна умова інноваційних змін та забезпечення конкурентоспроможності країни на основі ефективного використання інтелектуальних ресурсів. 3 початком формування ринку освітніх послуг в Україні набули актуальності питання стосовно ступеня участі держави у сфері освіти².

У період активного реформування освітньої галузі та стрімких змін, які $€$ наслідками оптимізації державного регулювання діяльності закладів вищої освіти, актуальності набуває пошук інноваційних

1 Павліха Н.В. Особливості розвитку регіональних ринків освітніх послуг в Україні. Економіка і суспільство. 2018. № 15. С. 540-544.

${ }^{2}$ Обгрунтування особливостей ринку освітніх послуг. Технологический аудит и резервы производства. 2014. № 4 (2). С. 36-39. 
підходів до управління та регулювання діяльності освітньої системи, які б мали чітке орієнтування на ключові зміни в державній освітній політиці в умовах європейської конвергенції.

Система управління освітньою галуззю не досить швидко реагує на зміни як у ринковій економіці, так і в базових сферах функціонування сучасного соціуму. Тому саме оптимізація, оновлення механізмів державного управління та регулювання освітньої галузі націлені на покращення якісних показників та результативності професійної діяльності керівників закладів вищої освіти. Впровадження інноваційного менеджменту сприяє розвитку таких фундаментальних якостей сучасного керівника, як володіння економічними і правовими знаннями та вміння ефективного їх застосування на практиці, високорозвинена здатність до самовдосконалення, розвитку компетенцій та професійної компетентності, інтегрованість професійних знань, здатність до креативного управління в умовах жорсткої конкуренції. Швидка інтеграція та глобалізація світової освітньої галузі стимулює розвиток української моделі управління системою вищої освіти 3 урахуванням нових підходів, теоретичних та методологічних основ процесу формування.

Протягом останніх років спеціалісти різноманітних галузей гуманітарного та соціального знання активно приділяють увагу вирішенню актуальних проблем функціонування вищої освіти. Пошук ефективних механізмів державного управління реформуванням вищої освіти в умовах європейської конвергенції $\epsilon$ предметом для наукового аналізу М.А. Ажажа, П.І. Алієва, О.І. Большої, С.А. Вавренюка, С.М. Домбровської, Ю.Д. Древаля, Н.В. Коржа, С.Р. Пасєки, У.М. Парпан, В.В. Сиченко, С.О. Рибкіної, Я.О. Тицька, Г.М. Чирви, В.М. Шевченко, М.О. Шкурат.

Мета статті - охарактеризувати особливості управління та державного регулювання системи освіти України в умовах європейської конвергенції просторово-економічних систем.

\section{1. Державне регулювання системи вищої освіти як об'єкт постійної оптимізації}

Освіта $є$ фундаментальним каталізатором змін, що відбуваються у суспільстві, при цьому всі зміни, що відбуваються у сфері політичних, економічних, соціальних відносин, здійснюють безпосередній вплив і на освітню сферу. Популяризація та деталізація глобальних процесів $є$ показовим викликом для вищої школи ${ }^{3}$. Інтернаціоналізація вищої освіти

\footnotetext{
${ }^{3}$ Інтернаціоналізація вищої освіти України в умовах полікультурного світового простору: стан, проблеми, перспективи. Маріуполь : МДУ, 2018. 646 с.
} 
спрямована на налагодження міжнародного співробітництва i стає фундаментом стратегії не тільки для закладів вищої освіти, а й для значної кількості державних освітніх структур та світових організацій загалом.

Конвергенція в освіті $\epsilon$ стабілізаційним фактором, що сприяє відбору оптимальних компонентів, перевірених у процесі тривалої освітньої практики. Це об’єднує ідеї розробки та впровадження освітніх стандартів, що гарантують функціональне забезпечення гарантованого мінімуму змісту базових освітніх програм, стандартизацію обсягів навчального навантаження, вимог до фахової підготовки майбутніх спеціалістів. На державному рівні це - гармонізація системи вищої освіти, що передбачає координацію вимог до знань студентів, інтеграція системи вищої освіти до стандартів Європейського простору; на регіональному рівні - інформаційна підтримка освітніх заходів для подальшого підвищення освіченості громадян; на рівні освітніх заходів - відкритість до запозичення форм, методів та засобів організації педагогічного процесу.

Конвергенція освітньої політики у цьому разі $є$ побічним продуктом економічної та соціальної політики. Прикладом є Європейський Союз, де конвергенція освітніх систем була наслідком гармонізації політичного та економічного життя. Однак конвергенція $є$ не стільки синонімом реформи, хоча часто i використовується в цьому взаємозв'язку. Конвергенція виступає більше причиною реформування. Здійснюються реформи 3 метою конвергенції національних систем освіти.

Державне управління вищою освітою передбачає цілеспрямований вплив суб'єктів управління різних рівнів на всі ланки освіти для гарантування та майбутнього розвитку соціального організму і культури суспільства; як різновид діяльності державних органів, що має розпорядчий i виконавчий характер, що проявляється в організованому впливі на соціальні взаємини у освітній галузі за рахунок оптимізації державно-владних повноважень, що передбачає цілеспрямоване формування, прийняття та реалізацію організаційних, регулюючих і контролюючих факторів впливу на освітню галузь 4 .

Законодавець комплексно підходить до визначення підгрунтя для формування й реалізації державної політики у сфері освіти, адже цей процес має бути виваженим, орієнтуватися на забезпечення прав конкретних осіб і всього суспільства. Так, формування і реалізація державної політики у сфері освіти здійснюється на основі наукових досліджень, міжнародних зобов'язань, вітчизняного та іноземного

${ }^{4}$ Сиченко В.В., Рибкіна С.О. Особливості державного управління у сфері освіти. Публічне управління та адміністрування у прочесах економічних реформ. Херсон : ДВНЗ «ХДАУ», 2019. 333 с. 
досвіду з урахуванням прогнозів, статистичних даних та індикаторів розвитку. Окрім того, вагоме значення для з'ясування правових аспектів реалізації державної політики у сфері освіти має визначення нормативно-правового базису такої політики. Так, загальні засади державної політики у сфері освіти визначені Конституцією України та іншими законами. Основним Законом України передбачаються принципи реалізації права на освіту, яке забезпечує держава (стаття 53); обов'язкове визначення засад регулювання освіти на рівні законодавства (стаття 92); забезпечення політики у сфері освіти Кабінетом Міністрів України (стаття 116) тощо .

Вирішальним фактором модернізації вищої освіти України повинна бути послідовність державного управління щодо вирішення завдань, визначених законами України «Про вищу освіту» та «Про освіту», Національною доктриною розвитку освіти України у XXI столітті, Державною національною програмою «Освіта: Україна XXI століття», Стратегією сталого розвитку «Україна - 2020», Національною стратегією розвитку освіти в Україні на період до 2021 року, Концепцією розвитку освіти України на період 2015-2025 років тощо.

Національною стратегією розвитку освіти в Україні на 2012$2021 \mathrm{pp}$. серед найважливіших пріоритетів державної політики визначено виховання людини інноваційного типу мислення та культури, проєктування акмеологічного освітнього простору з урахуванням інноваційного розвитку освіти, запитів особистості, потреб суспільства і держави ${ }^{6}$.

Питання державного регулювання освітньої галузі та іï одного 3 фундаментальних компонентів - системи вищої освіти - було і залишається предметом вивчення, дискусій, об'єктом постійної оптимізації. Україна в цьому плані не $є$ винятком, а навпаки, є одним з учасників досліджуваного процесу, залучення до якого гарантує через дію об'єктивних факторів позитивний чи деструктивний вплив на економічний розвиток. Також потрібно акцентувати увагу на наявності проблемних питань у забезпеченні повноцінного функціонування національної системи вищої школи, що потребують термінового вирішення.

Необхідність комплексної оцінки всіх компонентів, базових характеристик та умов функціонування механізмів державного управління в українській освітній системі вищої освіти, а особливо

5 Тицька Я.О. Державна політика у сфері освіти: правовий аспект. Прикарпатський юридичний вісник. 2018. № 2 (23). С. 55-60.

${ }^{6}$ Ажажа М.А. Напрями державного управління модернізацією освіти в контексті євроінтеграції України. Інвестиції: практика та досвід. 2018. № 8. С. 94-99. 
в напрямі іï розвитку, зумовлюється системою визначальних факторів. Вони зумовлені базовими перетвореннями у суспільстві, формуванням нових парадигм управління, зміною значення вищої освіти в українському суспільстві та новою якістю освітньої системи. Вивчення компонентів, факторів, умов i механізмів державного управління розвитком вищої освіти дає змогу сформувати загальну стратегію майбутніх змін, сформулювати практичні рекомендації, надати аргументований соціальний прогноз позитивних змін ${ }^{7}$.

Одним із завдань державного управління освітньою галуззю в ході реформування системи вищої освіти України, в умовах визначення євроінтеграційних пріоритетів та активних глобалізаційних та інформатизаційних процесів $\epsilon$ контроль над процесом створення оптимально наповненого освітнього простору закладу вищої освіти та забезпечення умов для його функціонування. Це зумовлює доцільність визначення оновлених освітніх стратегій щодо модернізації наявного освітнього простору студентів, прийняття управлінських рішень органами державної влади, що сприяють наближенню системи вищої освіти України до європейських освітніх стандартів.

Академічні організації, такі як органи акредитації, встановлюють критерії для оцінки якості програм навчання. Подібні вимоги у вигляді стандартів і норм встановлюються професійними союзами, такими як асоціації фірм та професійні організації.

Ринок освітніх послуг має забезпечувати сталий розвиток України. Адже він $\epsilon$ головним засобом формування та відтворення інтелектуального потенціалу нації, нової системи світогляду цінностей і духовності громадян. У цьому контексті пріоритетними завданнями досліджуваної сфери мають бути:

- розробка освітніх програм, що містять знання про взаємозалежність економічного процвітання, добробуту і здоров'я людини, соціальної справедливості та збереження навколишнього середовища, про межі допустимого втручання у природу;

- постійне вдосконалення спеціальних навчальних програм зі сталого розвитку у закладах освіти, створення навчальних посібників 3 питань екологічної етики та екологічної економіки, видання науковопопулярної літератури з цієї тематики;

- формування необхідного базису знань, що спирається на ідеї взаємозалежності природи і суспільства, сталого розвитку та економічної свідомості людини;

7 Домбровська С.М. Інноваційні державні механізми формування якісної системи освіти в Україні. Вища освіта України. 2013. № 3. С. 10-14. 
- створення загальнодержавної системи безперервної екологічної освіти і виховання, в т.ч. 3 питань сталого розвитку в усіх вікових групах населення;

- забезпечення постійної інформованості населення та громадських організацій, що $\epsilon$ найвищою формою еволюції індустріальної системи господарювання ${ }^{8}$.

Координація вищої освіти здійснюється на національному, регіональному та міжнародному рівнях. На національному рівні в більшості країн $є$ національні асоціації вчених, які проводять зустрічі на регулярній основі, щоб скоординувати сфери своїх досліджень (наприклад, Свропейська асоціація університетів (EUA), Міжнародна асоціація ректорів педагогічних університетів Європи). Останніми роками більшого значення набули регіональні групи як на академічному, так і на професійному рівнях, включаючи наприклад Свропейську раду аспірантів та молодих учених (Eurodoc).

Управління системи освіти в умовах європейської конвергенції повинно бути спрямоване на вирішення таких завдань, як':

організація вільного доступу до здобуття освітніх послуг, рівень яких задовольняє актуальні освітні потреби українського населення;

забезпечення умов для рівного доступу до здобуття вищої освіти для всіх бажаючих на всіх рівнях освітньої системи;

збільшення якості освітніх послуг та розвиток іiі відповідно до запиту суспільства;

підвищення результативності функціонування освітньої системи;

гарантування безперервності освітнього процесу;

дотримання принципу безоплатності вищої освіти за рахунок персоніфікації фінансування та розподілу бюджетних коштів, що розраховані на забезпечення освітніх потреб;

інтегрування закладів вищої освіти різних типів в об’єднання, асоціації;

розвиток конкурентоспроможного освітнього середовища.

Зміна вимог ринку праці вимагає перебудови освітніх програм 3ВО, впровадження міждисциплінарних програм, підготовки мультипрофесіонала, який зможе адаптуватися до постійно мінливого середовища, зумовленого глобалізаційними викликами. Наявність загрози втрати національної ідентичності студента визначає поштовх

8 Пойта I.О. Особливості формування ринку освітніх послуг. Національне господарство України: теорія $і$ практика управління. Київ : ДУ ІЕПСР НАН України, 2011. С. 249-253.

9 Державне управління реформуванням вищої освіти в Україні : монографія / С.А. Вавренюк. Харків : НУЦЗУ, 2020. 285 с. 
усієї національної освітньої системи до формування механізмів ефективного захисту національного освітнього простору, актуалізації принципу національної спрямованості самовизначення, формування у студентів відповідальної громадянської позиції.

Фундаментом непрямого механізму державного регулювання взаємодії $€$ внутрішній діалог підсистем, спрямований на забезпечення стандартизації та взаємозамінності базових компонентів простору освітньої системи. Перше відображає збільшення зовнішньоекономічної активності суб'єктів на міжнародному ринку за рахунок реалізації різноманітних форм інтернаціоналізації й транснаціоналізації освітнього процесу та породжує появу другого компонента імперативу упорядкування та узгодження між країнами в ході регулювання ролі різних учасників освітньої діяльності. Тобто обов'язково формується потреба в прийнятті міжнародних норм і правил ${ }^{10}$.

Протягом формування державної політики у сфері вищої освіти у сучасних умовах пріоритетною стала проблема якості вищої освіти, що проявляється у визначенні умов для повноцінного задоволення потреб громадян у якісних освітніх послугах на базі вищої школи, а в економічному аспекті - у кваліфікованих спеціалістах ${ }^{11}$.

Шлях до конвергенції стандартів вищої освіти полягає у визначенні загальних орієнтирів, недотримання яких свідчить про невідповідність національної системи освіти прогресивній міжнародній практиці. На цьому шляху стоять донорські агентства, які фінансують двосторонні та регіональні програми розвитку етики, цінностей, освіти, які управлінцю потрібно залучити та координувати їхню діяльність.

Завдяки правовій інституціоналізації механізмів освітнього управління відбувається закріплення певних загальних орієнтирів, які однозначно сприймаються як суспільством, так і державою. Такими орієнтирами для сучасної України є забезпечення прав людини на освіту, законність, а також життя, здоров'я, честь та гідність людини, національна безпека. Водночас освітня інституціоналізація механізмів та процедур державного управління дає можливість суспільству вимагати від держави і державної влади виконання своїх зобов'язань у всіх тих випадках, коли, на думку громадян, вона починає діяти

10 Алієва П.І. Організаційно-правовий механізм державного регулювання міжнародного співробітництва закладів вищої освіти. Вісник Національного університету циивільного захисту Украӥни. 2018. № 2. С. 239-245.

11 Чирва Г.М. Механізми державного управління розвитком вищої освіти: орієнтація на якість освітніх послуг. Публічне управління та митне адміністрування. 2019. № 3 (22). С. 146-156. 
відповідно до власних інтересів, ігноруючи при цьому інтереси як окремих громадян, так і суспільства загалом.

Зазначимо, що особливістю формування державної політики у сфері освітніх послуг в умовах євроінтеграції України $є$ те, що в процесі розвитку ринкових відносин і стабілізації економіки функції безпосереднього впливу держави на сферу освіти будуть мінімізуватися.

Отже, оптимізація державної політики у сфері вищої освіти повинна базуватись на непрямих та неформальних методах механізмів державного управління вищими закладами освіти ${ }^{12}$.

\section{2. Ефективність антикризового менеджменту}

\section{та фінансового контролю функціонування державних}

\section{та комунальних закладів вищої освіти}

Управлінські процеси пов'язані з можливістю появи фінансового, іміджевого, організаційного ризиків та ризиків, зумовлених кадровим забезпеченням та професійними ризиками педагогічних працівників. Управління закладом вищої освіти супроводжується ризиком погіршення іміджу закладу, зумовленого низькою популярністю його випускників на ринку праці, високим рівнем корупції, низькою толерантністю керівника, низьким кваліфікаційним рівнем. Зусилля керівництва закладу щодо формування позитивного іміджу мають бути спрямовані на всі сфери діяльності протягом усіх етапів його становлення, структуровані 3 урахуванням різних цільових груп. Організаційний ризик зумовлений слабкими внутрішніми взаємозв'язками організаційної структури закладу вищої освіти ${ }^{13}$.

Сьогодні освіта, як один із видів економічної діяльності, $\epsilon$ невід'ємною складовою частиною ринкової економіки України. Водночас економічний стан освіти в Україні характеризується суттєвою незбалансованістю. Ключовою проблемою економічних відносин у сфері освіти України $\epsilon$ невідповідність чинного економічного механізму засадам ринкової економіки.

Як і за часів планової радянської економіки, державні кошти на освіту виділяються на «утримання державних i комунальних навчальних закладів», а не на оплату вироблених і наданих закладами освіти конкретних видів освітніх послуг з урахуванням їх якості.

12 Шевченко В.М. Особливості формування механізмів державного управління вищими навчальними закладами в умовах євроінтеграції та інноваційного розвитку України. Державне будівництво. 2010. № 1. URL: http: //nbuv.gov.ua/UJRN/DeBu_2010_1_47.

${ }^{13}$ Корж Н.В. Ризик-менеджмент у реалізації системи управління якістю закладів вищої освіти. Держава та регіони. Серія: Економіка та підприємництво. 2019. № 4. C. 53-57. 
Насамперед такий механізм фінансування освітньої діяльності обмежує громадянам України можливість здобувати освіту за державні кошти за своїм вибором у навчальних закладах незалежно від місця їх розташування та форм власності, а отже, позбавляє можливості впровадити принцип «гроші ходять за здобувачем освіти». Крім того, чинний механізм фінансування освіти не дає змоги впровадити такий інструмент підвищення ефективності економічної діяльності, як конкуренція між закладами освіти, у результаті якої заклад освіти як суб’єкт господарювання може отримати додаткові кошти за більш якісні результати своєї освітньої діяльності ${ }^{14}$.

Державні та комунальні заклади вищої освіти функціонують в умовах неефективного фінансового контролю. Наявні обмеження $\epsilon$ перепонами на шляху забезпечення оперативного реагування на сучасні виклики та ефективного використання майна закладу. Система єдиної тарифної сітки породжує однорівневість у обсягах надходжень заробітних плат та унеможливлює функціонування ефективної системи винагороди викладачів відповідно до їх професійних здобутків.

Запровадження фінансової автономії закладів вищої освіти означає:

вихід державних та комунальних закладів вищої освіти зі статусу бюджетних установ 3 максимальним збереженням податкових, тарифних та митних преференцій, інших економічних та регуляторних умов, необхідних для їхнього успішного розвитку;

забезпечення права ЗВО самостійно затверджувати кошториси і вносити зміни до них;

відмову від державного регулювання чисельності науковопедагогічних працівників;

забезпечення права ЗВО самостійно встановлювати розміри оплати праці в межах їніх кошторисів. Передбачення можливості оплати гонорарів та заробітних плат іноземним викладачам за оптимізованими процедурами;

зарахування закладам вищої освіти 100\% орендної плати за їхнє майно, скасування погодження оренди майна, спрощення процедури списання застарілого майна;

запровадження механізму реалізації надлишкового майна та поступове виокремлення невластивої для ЗВО функції з управління базами відпочинку та житловим фондом, включаючи гуртожитки;

стимулювання формування та використання сталих фондів (ендавментів). Започаткування (spin-off) бізнес-проєктів.

14 Ринок освітніх послуг: виклики сучасності : збірник матеріалів науковопрактичної конференції з міжнародною участю (м. Київ, 11 червня 2019 р.). Київ : АПСВТ, $2019.98 \mathrm{c}$. 
Внутрішні ризики суттєво мінімізують ефективність управління закладом вищої освіти. Епіцентри формування ризиків можуть виникати як у кадровій політиці, так і під час формування контингенту студентів, інвестиційної діяльності. Більшість ризиків внутрішнього середовища закладу вищої освіти прямо чи опосередковано чинить негативний вплив на фінансовий потенціал $3 \mathrm{BO}$ та його конкурентоспроможність. Для успішного здійснення освітньої діяльності необхідно своєчасно ідентифікувати ризики і підвищувати ефективність управління ними. Для цього важливо використовувати вищеописані важелі впливу на внутрішні ризики.

Ситуація, що на поточний момент генерує кризу в Україні, унеможливлює швидке й дієве реагування та подолання негативних результатів і впливів. Кризові ситуації руйнують усталені зв'язки, закономірності, традиційні схеми дій в освітній системі загалом, а також в окремій освітній установі. За такої умови зростає потреба у висококваліфікованих управлінських, педагогічних, науковопедагогічних кадрах, що здатні пристосуватись до нових, кризових умов роботи та подолати негативні наслідки кризи.

Незалежно від зовнішніх впливів у самому закладі вищої освіти постійно виникають проблеми, такі як конфліктні ситуації, застосування застарілих технологій, втрата конкурентних позицій на ринку освітніх послуг, відтік кадрів і ресурсів тощо. Усе це може призвести до зниження показників діяльності закладу освіти.

Засновники та органи управління закладами вищої освіти обмежені в реакції на кризові ситуації, коли лише оперативне оновлення менеджменту може врятувати від згубних наслідків. Для уникнення таких ситуацій за засновником має бути закріплене право призначити антикризовий менеджмент в університеті строком до трьох років у разі настання виняткових обставин, в яких традиційне управління $\epsilon$ неефективним.

Менеджмент у сфері регулювання ринку освітніх послуг (із застосуванням підходів гнучкого, економічного, підприємницького, соціального та освітнього управління) покликаний забезпечити їх ефективність 3 виробництва освітнього продукту (освітньої послуги), попереджати ризики та оперативно реагувати на зміни відповідно до поточних суспільних потреб, кон'юнктури регіонального ринку, а також стратегічних факторів розвитку країни та iï регіонів у контексті вимог інноваційної економіки знань. Сучасний ринок праці України потребує кваліфікованої робочої сили, яка володіє прогресивними 
знаннями та технологіями і здатна до постійного їх оновлення, тобто до безперервного самонавчання та самовдосконалення упродовж життя ${ }^{15}$.

\section{3. Роль інноваційного менеджменту у впровадженні сучасної європейської освіти в Україні}

Сталий і динамічний розвиток освіти пов'язаний із формуванням ефективної інноваційної політики держави. Інноваційна діяльність навчальних закладів постійно перебуває в єдності та боротьбі суперечностей. 3 одного боку, налагодженість у роботі, старий уклад закладу, що часто опирається нововведенням, і з іншого боку, здобуття й підтримання конкурентоспроможності засобом інноваційних змін. Неможливо упровадити нове й ефективне, не ризикуючи.

Менеджери закладів освіти мають розвивати власні особистісні якості, фаховість, інноваційну культуру та компетентність. Саме від інноваційного менеджменту залежить успішність інноваційної діяльності освітньої установи. Новації вдосконалюють діяльність колективу, дають змогу працювати творчо, задовольняють освітні потреби, відкривають нові можливості для кожного учасника освітнього процесу.

Слід суттєво підвищити якість професійної підготовки на всіх рівнях освіти шляхом спрямованості іiі на міжнародні стандарти, орієнтації освітніх установ на потреби регіонального, локального і місцевого ринків праці. $€$ необхідність якісної зміни системи співпраці територіальних і державних установ щодо питань функціонування i розвитку професійного навчання. Динамічній моделі соціально-економічного розвитку країни повинна відповідати адаптивна система освіти, яка здатна швидко реагувати на зміну вимог ринку праці, зміну темпів економічного зростання, готувати і відтворювати фахівців, що здатні працювати в конкурентному середовищі. Багаторічна практика регіонального розвитку доводить, що конкурентоспроможність регіону залежить від якості освіти та інновацій як основних факторів економічного розвитку країни загалом ${ }^{16}$.

Освітня сфера $є$ чинником піднесення рівня якості життя населення, а розвиток регіональних ринків освітніх послуг - пріоритетним напрямом державної та регіональної політики у сфері освіти України.

Високий інноваційний потенціал свідчить про спроможність закладу провадити інноваційний пошук, зміни, інноваційні стратегії.

15 Пасєка С.Р. Трансформація освітнього менеджменту на етапі інноваційних змін. Фінансовий простір, 2013. № 4. С. 217-221.

${ }^{16}$ Большая О.В. Функціонування ринку освітніх послуг та ринку праці України. Витоки педагогічної майстерності. 2019. № 24 С. 5-9. 
Заклади 3 низьким інноваційним потенціалом не забезпечують розвитку навчального закладу.

Інноваційний менеджмент закладів вищої освіти дає змогу сформувати більш інноваційні навчально-освітні програми, сприяє формуванню інноваційного механізму управління, підвищує результативність його функціонування. Інновації в управлінні закладом вищої освіти є своєрідним переходом до результативно-орієнтованого менеджменту.

Пріоритетними напрямами державної політики України щодо розвитку вищої освіти $\epsilon^{17}$ : особистісна орієнтація вищої освіти; формування національних і загальнолюдських цінностей; створення для громадян рівних можливостей у здобутті вищої освіти; постійне підвищення якості освіти, оновлення іiі змісту та форм організації освітнього процесу; запровадження освітніх інновацій та інформаційних технологій; формування у системі освіти нормативноправових i організаційно-економічних механізмів залучення і використання позабюджетних коштів; підвищення соціального статусу i професіоналізму педагогічних працівників, посилення їх державної і суспільної підтримки; розвиток освіти як відкритої державно-суспільної системи; інтеграція вітчизняної вищої освіти до європейського та світового освітніх просторів.

Впровадження сучасної європейської освіти в Україні без інноваційного менеджменту неможливе. Лише від ступеневої підготовки фахівців, потужної наукової бази, управлінської ланки, завдяки мобільності учасників освітнього простору зміни в управлінні освітою та впровадження новацій дають свої перші позитивні результати. Шлях до прогресивних змін у суспільно-політичному та економічному житті держави лежить у площині зміни освітнього менеджменту. Лише завдяки змінам у системі управління освітою можливий стимул до інноваційної діяльності, розвитку та впровадження індивідуального стилю керівництва та підвищення рівня культури майбутніх поколінь. Реформація менеджменту освіти дає змогу підвищити освітньо-кваліфікаційний рівень населення, інноваційну активність працівників, відкриває нові можливості для формування і підвищення конкурентоспроможності робочої сили, яка формується на базі закладів освіти ${ }^{18}$.

17 Парпан У.М. Провідні принципи розвитку сучасної вищої освіти України в контексті євроінтеграції. Lex portus. 2018. № 1. С. 62-71.

${ }^{18}$ Большая O.I. Інноваційний менеджмент у сучасній освіті. Витоки педагогічної майстерності. 2018. № 22. С. 31-34. 
Нині вся система вищої освіти та державне управління у сфері освітніх послуг зазнають певних прогресивних змін, які пов'язані 3 вирішенням проблемних завдань i були сформульовані у Національній доктрині, а потім у Національній стратегії розвитку освіти України, основні $з$ яких, на нашу думку, такі ${ }^{19}$ :

- підвищення якості та ефективності освіти шляхом консолідації зусиль суспільства (держава - громадськість - навчальний заклад) на основі ефективного використання інформаційно-інноваційних технологій;

- упровадження інноваційних навчально-методичних, освітньотехнологічних та організаційно-управлінських елементів у освітній процес задля формування сприятливого інформаційно-інноваційного середовища у сфері вищої освіти;

- формування ефективної системи державного управління вищою освітою в Україні на основі принципів Болонської декларації: автономії, відповідальності та диверсифікації.

Якісні зміни у системі вищої освіти повинні супроводжуватися також удосконаленням ціннісних пріоритетів українського суспільства $^{20}$. Реформування вищої освіти в Україні повинне відбуватися систематично 3 урахуванням та із використанням різноманітних механізмів державного управління. У конкретному/ конкретно-цільовому контексті насамперед має йтися про повноцінне застосування правового, комунікативного, організаційного, інноваційного, інформаційного та ціннісно-орієнтаційних механізмів державного управління вищою освітою. Саме на зазначеному фундаменті визначається вірогідним досягнення рівня вищої освіти, що дозволятиме перетворення набутих знань на здатність людини до професійної творчої діяльності. Це, власне, і є основою інноваційної вищої освіти в європейському просторі.

\section{ВИСНОВКИ}

Упровадження сучасного управління у закладах вищої освіти в умовах європейської конвергенції $\epsilon$ можливим за умови дотримання низки умов:

- соціально-педагогічні умови, що передбачають дотримання принципів демократизації та гуманізації освітнього процесу в процесі

19 Шкурат М.О. Інформаційно-інноваційний механізм державного управління якістю вищої освіти в Україні у світлі євроінтеграції. Публічне управління та митне адміністрування. 2019. № 3 (22). С. 167-177.

${ }^{20}$ Древаль Ю.Д. Механізми державного управління вищою освітою в Україні: проблеми формування та вдосконалення. Вісник Національного університету цивільного захисту Украӥни. 2014. № 2. С. 107-111. 
управління ним, забезпечення необхідних передумов для творчого зростання педагогічного та студентського колективів, представників адміністративного апарату 3 метою подальшого залучення їх до проведення експериментально-дослідницької діяльності;

- психолого-педагогічні умови, що орієнтовані на забезпечення постійного швидкісного інформування співробітників 3 науковопедагогічних питань та участі закладу в інноваційних проєктах та асоціаціях, на інституційне забезпечення освітнього процесу та зростання кваліфікаційного рівня суб'єктів освітнього процесу, формування у працівників 3ВО інноваційної культури;

- організаційно-педагогічні, які спрямовані на забезпечення фінансування діяльності закладу в євроінтеграційному руслі розвитку та розробка системи стимулювання для реалізації освітніх пріоритетів за рахунок встановлення системних зв'язків з іншими українськими та європейськими науковими установами та організаціями.

\section{АНОТАЦІЯ}

Автором зазначено змістове наповнення державного управління вищою освітою в умовах європейської конвергенції. Відзначено важливість комплексної оцінки всіх компонентів, базових характеристик та умов функціонування механізмів державного управління в українській освітній системі вищої освіти. Виявлені завдання державного управління освітньою галуззю в ході реформування системи вищої освіти України, в умовах визначення євроінтеграційних пріоритетів та активних глобалізаційних та інформатизаційних процесів. Охарактеризовано фінансові аспекти державного регулювання системи вищої освіти України. Визначені ризики, які впливають на процес управління закладами вищої освіти. Проаналізовані ключові нормативно-правові документи, які здійснюють вплив на становлення державного регулювання системи освіти України.

\section{ЛITЕРАТУРА}

1. Павліха Н.В. Особливості розвитку регіональних ринків освітніх послуг в Україні. Економіка і суспільство. 2018. № 15. С. 540-544.

2. Обгрунтування особливостей ринку освітніх послуг. Технологический аудит и резервы производства. 2014. № 4 (2). С. 36-39.

3. Інтернаціоналізація вищої освіти України в умовах полікультурного світового простору: стан, проблеми, перспективи. Маріуполь : МДУ, 2018. 646 с. 
4. Сиченко В.В., Рибкіна С.О. Особливості державного управління у сфері освіти. Публічне управління та адміністрування у процесах економічних реформ. Херсон : ДВНЗ «ХДАУ», 2019. 333 с.

5. Тицька Я.О. Державна політика у сфері освіти: правовий аспект. Прикарпатський юридичний вісник. 2018. № 2 (23). С. 55-60.

6. Ажажа М.А. Напрями державного управління модернізацією освіти в контексті євроінтеграції України. Інвестиції: практика та досвід. 2018. № 8. С. 94-99.

7. Домбровська С.М. Інноваційні державні механізми формування якісної системи освіти в Україні. Вища освіта України. 2013. № 3. С. $10-14$.

8. Пойта І.О. Особливості формування ринку освітніх послуг. Національне господарство України: теорія і практика управління. Київ : ДУ ІЕПСР НАН України, 2011. С. 249-253.

9. Державне управління реформуванням вищої освіти в Україні : монографія / С.А. Вавренюк. Харків : НУЦЗУ, 2020. 285 с.

10. Алієва П.I. Організаційно-правовий механізм державного регулювання міжнародного співробітництва закладів вищої освіти. Вісник Національного університету ичивільного захисту Украӥни. 2018. № 2. C. 239-245.

11. Чирва Г.М. Механізми державного управління розвитком вищої освіти: орієнтація на якість освітніх послуг. Публічне управління та митне адміністрування. 2019. № 3 (22). С. 146-156.

12. Шевченко В.М. Особливості формування механізмів державного управління вищими навчальними закладами в умовах євроінтеграції та інноваційного розвитку України. Державне будівництвво. 2010. № 1. URL: http: /nbuv.gov.ua/UJRN/DeBu_2010_1_47.

13. Корж Н.В. Ризик-менеджмент у реалізації системи управління якістю закладів вищої освіти. Держсава та регіони. Серія: Економіка та підприємництво. 2019. № 4. С. 53-57.

14. Ринок освітніх послуг: виклики сучасності : збірник матеріалів науково-практичної конферениії з міжнародною участю (м. Київ, 11 червня 2019 р.). Київ : АПСВТ, 2019.98 с.

15. Пасєка С.Р. Трансформація освітнього менеджменту на етапі інноваційних змін. Фінансовий простір, 2013. № 4. С. 217-221.

16. Парпан У.М. Провідні принципи розвитку сучасної вищої освіти України в контексті євроінтеграції. Lex portus. 2018. № 1. С. 62-71.

17. Большая О.I. Інноваційний менеджмент у сучасній освіті. Витоки педагогічної майстерності. 2018. № 22. С. 31-34.

18. Шкурат М.О. Інформаційно-інноваційний механізм державного управління якістю вищої освіти в Україні у світлі євроінтеграції. 
Публічне управління та митне адміністрування. 2019. № 3 (22). C. $167-177$.

19. Древаль Ю.Д. Механізми державного управління вищою освітою в Україні: проблеми формування та вдосконалення. Вісник Національного університету ичивільного захисту Украӥни. 2014. № 2. C. 107-111.

\section{Information about the author:}

Masliak T. R.,

Postgraduate Student at the Department of Management and Business Administration

Vasyl Stefanyk Precarpathian National University 57, Shevchenka str., Ivano-Frankivsk, 76000, Ukraine 